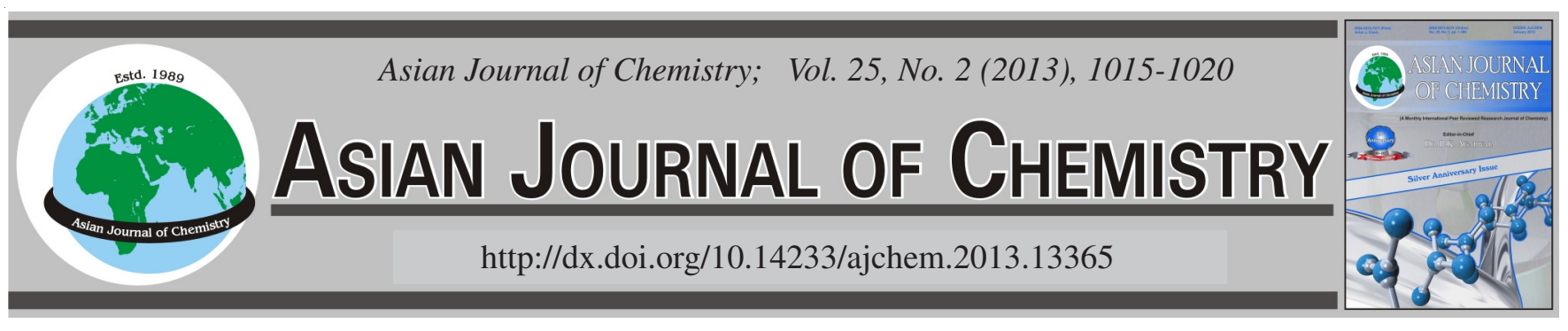

\title{
Assessment of Potential Toxicity of Alizarin Through Resonance Light Scattering
}

\author{
Cha-Cha Li, Jun-Sheng Li", Guo-Xia Huang, Qi-Qian Li and Liu-Juan Yan
}

Department of Biological and Chemical Engineering, Guangxi University of Technology, Liuzhou 545006, Guangxi Province, P.R. China

*Corresponding author: Fax: +86 772 2687033; Tel: +86 772 2685200; E-mail: junshenglee63@yahoo.com.cn

\begin{abstract}
Alizarin is a kind of natural pigment. In this paper, saturation value binding with DNA of alizarin can be calculated by the resonance scattering spectrum and then is compared with mitoxantrone, chrysophano and rhein. Alizarin's potential toxicity is far lower than mitoxantrone and is slightly lower than chrysophano and rhein. The saturation value binding with DNA of alizarin can be influenced by many factors through studying different factors that influence the saturation value, that means the potential toxicity of alizarin are influenced by many factors. The saturation value at alizarin-DNA-pH 7.46 is 0.20 . The saturation value at alizarin-DNA-pH 7.46-valine, alizarinDNA-pH 7.46-leucine, alizarin-DNA-pH 7.46-histidine, alizarin-DNA-pH 7.46-aspartate, alizarin-DNA-pH 7.46- tryptophan, alizarinDNA-pH 7.46-sodium chloride, alizarin-DNA-pH 7.46-glucose, alizarin-DNA-pH 6.44 and alizarin-DNA-pH 8.21 are 0.20, 0.20, 0.19, $0.24,0.30,0.4,0.17,0.17$ and 0.19 respectively. Their change rate of the saturation value binding with DNA with alizarin-DNA-pH 7.46 as a standard are $0,0,-5 \%,+20 \%,+50 \%,+50 \%,+100 \%,-15 \%,-15 \%$ and $-5 \%$. The aim of this paper is to provide a theoretical basis in using alizarin.
\end{abstract}

Key Words: Alizarin, Resonance light scattering, Potential toxicity, Saturation value binding with DNA.

\section{INTRODUCTION}

Alizarin has been used as a natural pigment since ancient times ${ }^{1-3}$, it is a component of madder colour that extracted from the roots of Rubia tinctorum L. It generally presume that most of the natural pigments have no side effect and are high safety. The mutagenicities of alizarin was examined in Salmonella typhimurium strains TA98, TA100 and TA2637 by the preincubation method and alizarin was strong mutagens in strain TA2637 with metabolic activation by Tikkanen et al. ${ }^{4}$. Inoue et al. ${ }^{5}$ reported that alizarin demonstrated carcinogenic potential in the kidney, liver and large intestine respectively and it can increase renal preneoplastic and alizarin might respectively be involved in renal carcinogenesis through oxidative and direct DNA damage by a rat medium-term multi-organ bioassay. Inoue et $a l .{ }^{6}$ observed the weight change of organs after feeding rat with alizarin. They found that alizarin has potential toxicity in kidney, liver and large intestine. The chemical name for alizarin is 1,2-dihydroxyanthraquinone, it is an anthraquinone derivative. Anthraquinone or its derivatives are toxic to human body. It has been reported that anthraquinone and its derivatives have carcinogenicity and mutagenicity and can induce tumors in the liver, kidney and urinary bladder $^{7-9}$. This paper, using resonance light scattering spectrum and molecular intercalator theory to research the potential toxicity of alizarin.

\section{EXPERIMENTAL}

A Shimadzu RF-5301PC fluorophotometer (Kyoto, Japan) with a quartz cell of $1 \mathrm{~cm}$ path length is used to measure the resonance light scattering spectrum.

Natural double DNA used in this study is herring sperm DNA (fs DNA, sigma). The stock solution were prepared by dissolving $0.0151 \mathrm{~g}$ solid DNA in $50 \mathrm{~mL}$ doubly distilled water with occasionally gentle shaking and stored at $4{ }^{\circ} \mathrm{C}$. Next day, dilute the stock solution into $500 \mathrm{~mL}$. The concentration of DNA solution was determined by UV absorption at $260 \mathrm{~nm}$ using the molar absorption coefficient $\varepsilon_{260}=6600 \mathrm{~mol}^{-1} \mathrm{~cm}^{-1}$. Concentration of DNA was $1.03 \times 10^{-4} \mathrm{~mol} / \mathrm{L}$ according to Bouguer-Lambert-Beer law in the experiment.

The stock solution of $1.0 \times 10^{-2} \mathrm{~mol} / \mathrm{L}$ histidine, lysine, aspartate, threonine, tryptophane, leucine, valine, sodium chloride and glucose (Fine Chemicals of Tianjin Siyou Limited Company) were prepared by distilled water. Dilute to $1.0 \times$ $10^{-4} \mathrm{~mol} / \mathrm{L}$ when they are used.

A Britton-Robinson buffer was used to control the $\mathrm{pH}$ of the reaction system. In this study, six buffers viz., $\mathrm{pH} 5.45, \mathrm{pH}$ 6.44, $\mathrm{pH} 7.46, \mathrm{pH} 7.4, \mathrm{pH} 8.21$ and $\mathrm{pH} 9.79$ were used. All reagents were of analytical reagent grade and doubly distilled water was used throughout the experiments.

Resonance light scattering spectrum of alizarin: Place $0.2 \mathrm{~mL}$ working solution of alizarin and $1 \mathrm{~mL}$ pH 7.46 buffer 
solution into a $10 \mathrm{~mL}$ volumetric flask, vortex and then add appropriate DNA solution, respectively. Then using double distilled water to dilute the mixture to $5 \mathrm{~mL}$ scale mark and mix thoroughly and locate them at $37^{\circ} \mathrm{C}$ water for $20 \mathrm{~min}$. The resonance light scattering spectrum was obtained by scanning simultaneously the excitation and emission monochromators of RF-5301 PC spectrofluorometer from 220 to $700 \mathrm{~nm}$. The extent of light scattering was measured at the maximum wavelength with slit width at $15 \mathrm{~nm}$ for the excitation and emission. To get the resonance light scattering spectrum of mitoxantrone, chrysophano and rhein same procedure has been adopted.

\section{RESULTS AND DISCUSSION}

The resonance light scattering signal of DNA is weak, but when added alizarin, mitoxantrone, chrysophanol and rhein, the signal enhanced. Yang ${ }^{12,13}$ has got the resonance light scattering spectrum of them at $\mathrm{pH} 7.4$. We get the resonance light scattering spectrum of them at $\mathrm{pH} 7.46$ (Figs. 1-3). Alizarin-DNA interaction results in strong enhanced resonance light scattering signals characterized by three peaks at 299 , $467,563 \mathrm{~nm}$ and peaks at $299 \mathrm{~nm}$ are sensitive and stable (Fig. 4).

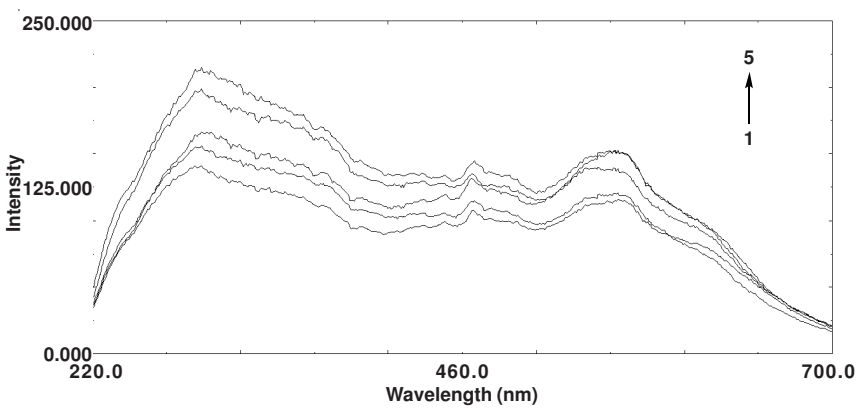

Fig. 1. Resonance light scattering spectra of DNA and mitoxantrone $\mathrm{C}_{\text {mitoxantrone }} 1-6: 1.125 \times 10^{-6} \mathrm{~mol} / \mathrm{L} ; \mathrm{C}_{\mathrm{DNA}} 1-6: 0,3.52 \times 10^{-7}, 2.2 \times 10^{-7}$, $2.86 \times 10^{-7}, 3.30 \times 10^{-7} \mathrm{~mol} / \mathrm{L}$

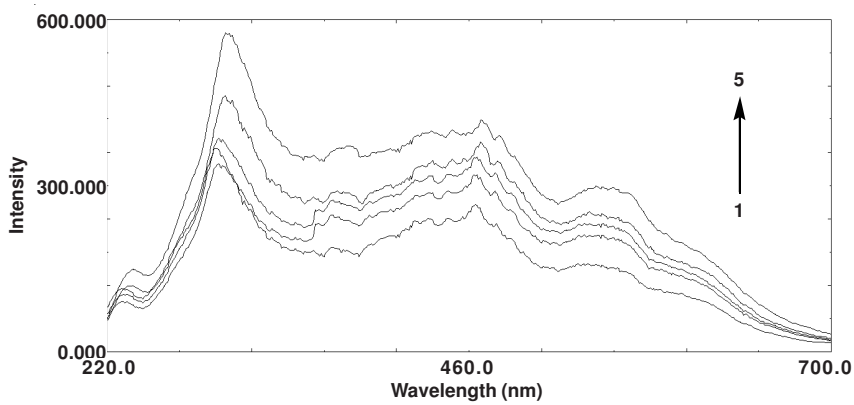

Fig. 2. Resonance light scattering spectra of DNA and chrysophanol $\mathrm{C}_{\text {chrysophanol }} 1-5: 1.42 \times 10^{-6} \mathrm{~mol} / \mathrm{L} ; \mathrm{C}_{\mathrm{DNA}} 1-5: 0,2.42 \times 10^{-6}, 2.53 \times 10^{-6}$, $2.75 \times 10^{-6}, 2.64 \times 10^{-6} \mathrm{~mol} / \mathrm{L}$

Saturation value binding with DNA of alizarin: Binding site and binding site number of DNA for anthraquinone molecule is certain because the molecular structure and substitute group is certain for a special anthraquinone molecule. When the concentration of anthraquinone (alizarin in this paper) is overdosed, the resonance light scattering signals gradually enhance with the increase of DNA concentration, but when the DNA concentration reach the limit, the resonance light scattering signal is no longer enhanced. The concentration of DNA is called as the saturated DNA concentration of anthraquinone molecular binding with DNA and the saturation value binding with DNA = anthraquinone molecular concentration/ the saturated concentration of $\mathrm{DNA}^{10}$. The bigger the saturation value, the stronger ability of intercalating into DNA will be, so transcription, replication of DNA and expression of genetic information will be hindered more. So its potential toxicity of anthraquinone molecular will be stronger.

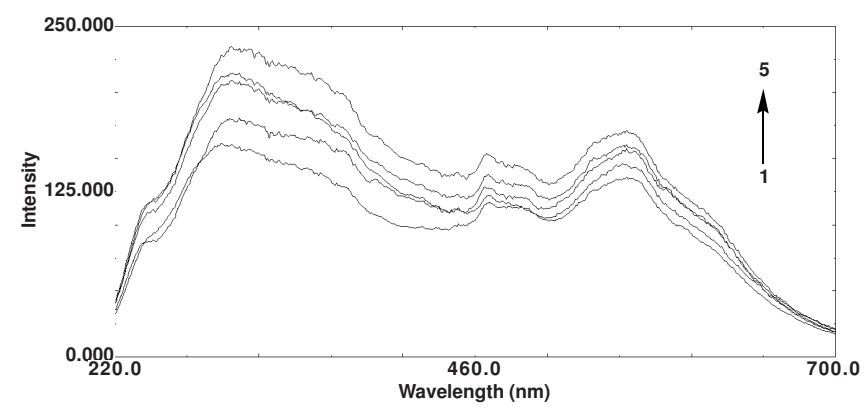

Fig. 3. Resononance light scattering spectra of DNA rhein $C_{\text {rhein }} 1-6: 5.63 \times$ $10^{-6} \mathrm{~mol} / \mathrm{L} ; \mathrm{C}_{\mathrm{DNA}} 1-5: 0,6.60 \times 10^{-6}, 8.80 \times 10^{-6}, 7.48 \times 10^{-6}, 8.14 \times$ $10^{-6} \mathrm{~mol} / \mathrm{L}$

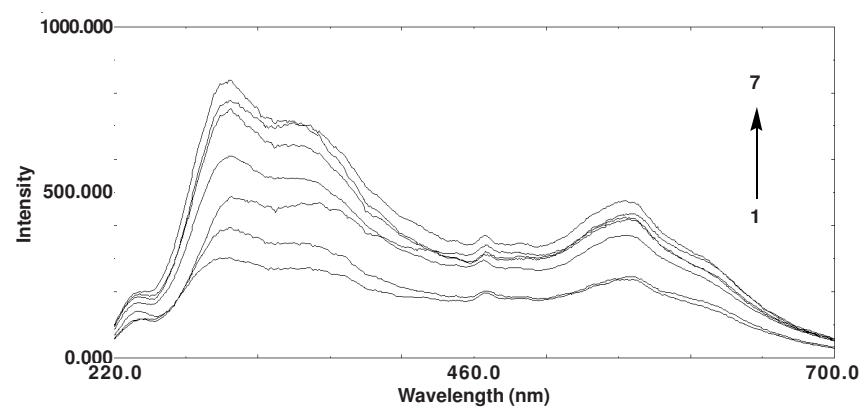

Fig. 4. Resonance light scatting spectra, of DNA and alizarin $\mathrm{C}_{\text {alizarin }}, 2-7: 5$ $\times 10^{-6} \mathrm{~mol} / \mathrm{L} ; \mathrm{C}_{\mathrm{DNA}} 1-7: 0,2.09 \times 10^{-5} 2.86 \times 10^{-5}, 2.44 \times 10^{-5} 2.75 \times$ $10^{-5}, 2.46 \times 10^{-5}, 2.64 \times 10^{-5} \mathrm{~mol} / \mathrm{L}$

Mitoxantrone is a synthetic anticancer agent that exhibits broad antitumor activity and it has been used effectively against breast cancer, acute leukaemia and malignant lymphomas. Chrysophanol and rhein are anthraquinone derivatives, they have side-effects ${ }^{11}$. Mitoxantrone, chrysophanol, rhein intercalate into DNA as intercalaters. The phenomenon of resonance light scattering of alizarin with DNA are similar to mitoxantrone, chrysophanol and rhein, so alizarin may be intercalate into DNA as DNA intercalators.

Yang $^{10,12,13}$ acquired the saturation value of mitoxantrone, chrysophano and rhein at $\mathrm{pH} 7.4$, the saturation value of them at $\mathrm{pH} 7.46$ are acquired in this paper. Selected resonance light scattering peak at $299 \mathrm{~nm}$ to investigate alizarin. Alizarin's saturation value at $\mathrm{pH} 7.4$ is 0.19 (Fig. 4) and at $\mathrm{pH} 7.46$ is 0.20 (Fig. 5). It indicates that the saturation value binding with DNA of alizarin are smaller than other anthraquinone derivatives (Tables 1 and 2). Its potential toxicity is much lower than mitoxantrone and is little lower than chrysophano and rhein.

Influence of histidine on the system of alizarin-DNA: Alizarin $\left(5 \times 10^{-6} \mathrm{~mol} / \mathrm{L}\right)$ and DNA $\left(2.47 \times 10^{-5} \mathrm{~mol} / \mathrm{L}\right)$ are fixed and the intensity of resonance light scattering in the 299 $\mathrm{nm}$ are different with the increasing concentration of histidine 


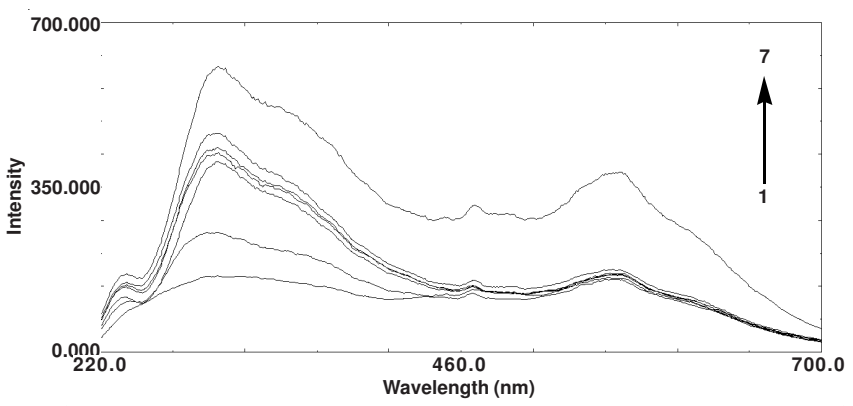

Fig. 5. Resonance light scatting spectra of DNA and alizarin $\mathrm{C}_{\text {alizarin }}$ : 2-7:5 $\times 10^{-6} \mathrm{~mol} / \mathrm{L} ; \mathrm{C}_{\mathrm{DNA}} 1-7: 2.06 \times 10^{-6}, 0,2.88 \times 10^{-5}, 1.44 \times 10^{-5}, 1.65 \times$ $10^{-5}, 2.06 \times 10^{-5}, 2.47 \times 10^{-5} \mathrm{~mol} / \mathrm{L}$

TABLE-1

SATURATION VALUE OF ANTHRAQUINONE DERIVATIVES OF BINDING DNA AT $\mathrm{pH} 7.4$

\begin{tabular}{lcc}
\hline $\begin{array}{c}\text { Anthraquinone } \\
\text { derivatives }\end{array}$ & $\begin{array}{c}\text { Saturation value } \\
\text { binding with DNA }\end{array}$ & $\begin{array}{c}\text { Saturation value of } \\
\text { anthraquiones/saturation } \\
\text { value of mitoxantrone (\%) }\end{array}$ \\
\hline Mitoxantrone & $3.31^{10,12,13}$ & 100 \\
Chrysophanol & $0.53^{10,12,13}$ & 16.0 \\
Rhein & $0.66^{10,12,13}$ & 19.9 \\
Alizarin & 0.19 & 5.74 \\
\hline
\end{tabular}

TABLE-2

SATURATION VALUE OF ANTHRAQUINONE DERIVATIVES OF BINDING DNA AT $\mathrm{pH} 7.46$

\begin{tabular}{lcc}
\hline $\begin{array}{c}\text { Anthraquinone } \\
\text { Derivatives }\end{array}$ & $\begin{array}{c}\text { Saturation Value } \\
\text { Binding with DNA }\end{array}$ & $\begin{array}{c}\text { Saturation value of } \\
\text { anthraquiones/saturation } \\
\text { value of mitoxantrone (\%) }\end{array}$ \\
\hline Mitoxantrone & 3.41 & 100 \\
Chrysophanol & 0.54 & 16.3 \\
Rhein & 0.69 & 20.2 \\
Alizarin & 0.20 & 5.86 \\
\hline
\end{tabular}

(Fig. 6). When concentration of histidine is $1 \times 10^{-6} \mathrm{~mol} / \mathrm{L}$, influence on the system of alizarin-DNA is greatest. Alizarin $\left(5 \times 10^{-6} \mathrm{~mol} / \mathrm{L}\right)$ and histidine $\left(1 \times 10^{-6} \mathrm{~mol} / \mathrm{L}\right)$ are selected, resonance light scattering at $299 \mathrm{~nm}$ gradually enhance with the increasing the concentration of DNA. When the concentration of DNA is greater than $2.68 \times 10^{-5} \mathrm{~mol} / \mathrm{L}$, resonance light scattering unchanged or decreased (Fig.7). The concentration of DNA at this time is called as the saturated DNA concentration of alizarin binding with DNA. The saturation value binding with DNA of histidine is 0.19 . Alkaline histidine combine with phosphate of DNA, which makes alizarin can not combine with phosphate of DNA. This makes alizarin are hindered to intercalate into DNA further.

Histidine is a semi-essential amino acid which is needed for body. It is important for growths of infants and animals. It can reduce the potential toxicity of alizarin.

Influence of aspartate on the system of alizarin-DNA: Alizarin $\left(5 \times 10^{-6} \mathrm{~mol} / \mathrm{L}\right)$ and DNA $\left(2.47 \times 10^{-5} \mathrm{~mol} / \mathrm{L}\right)$ are fixed and the intensity of resonance light scattering in the $299 \mathrm{~nm}$ are different with the increasing concentration of aspartate acid (Fig. 8). When concentration of aspartate is $1 \times 10^{-8} \mathrm{~mol} / \mathrm{L}$, influence on the system of alizarin-DNA is greatest. Alizarin $\left(5 \times 10^{-6} \mathrm{~mol} / \mathrm{L}\right)$ and histidine $\left(1 \times 10^{-8} \mathrm{~mol} / \mathrm{L}\right)$ are selected, resonance light scattering at $299 \mathrm{~nm}$ gradually enhance with the increasing the concentration of DNA. When the concentration of DNA is greater than $2.06 \times 10^{-5} \mathrm{~mol} / \mathrm{L}$, resonance

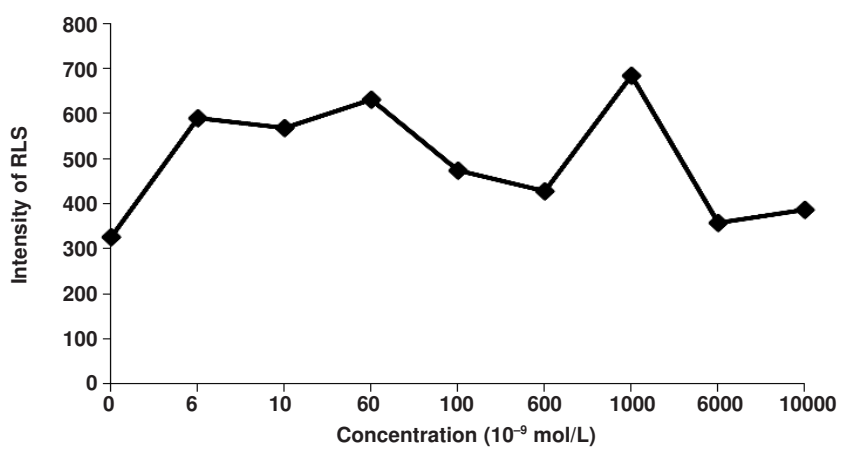

Fig. 6. Resonance scattering intensity of different the concentration of histidine on the system of alizarin and DNA

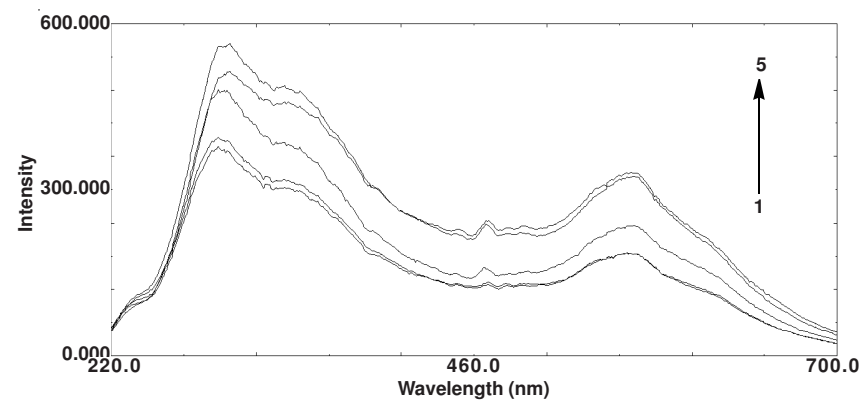

Fig. 7. Resonance scattering intensity of DNA, histidine and alizarin $\mathrm{C}_{\text {alizarin }}$ : $1-5: 5 \times 10^{-6} \mathrm{~mol} / \mathrm{L} ; \mathrm{C}_{\text {histidine }} 1-5: 1 \times 10^{-6} \mathrm{~mol} / \mathrm{L} ; \mathrm{C}_{\mathrm{DNA}}: 1-5: 0,2.06 \times$ $10^{-5}, 2.47 \times 10^{-5}, 2.88 \times 10^{-5}, 2.68 \times 10^{-5} \mathrm{~mol} / \mathrm{L}$

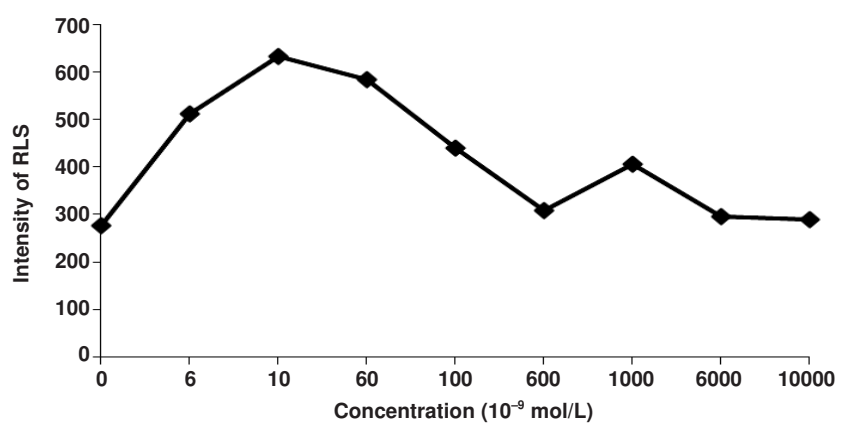

Fig. 8. Resonance scattering intensity of different the concentration of aspartate on the system of alizarin and DNA

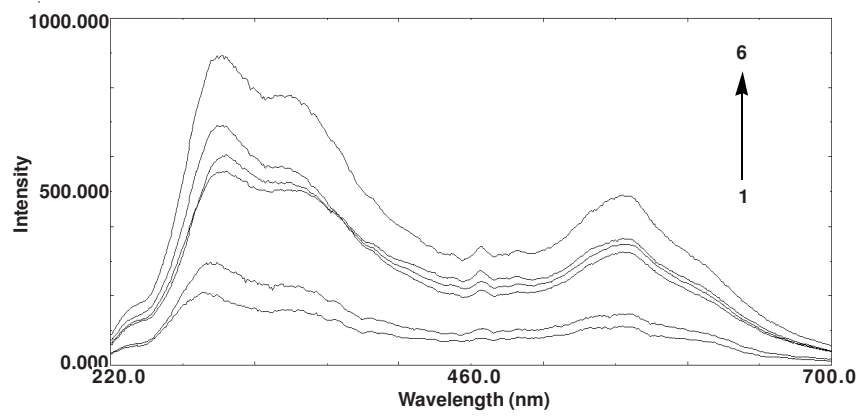

Fig. 9. Resonance scattering intensity of DNA, aspartate acid and alizarin $\mathrm{C}_{\text {alizarin }}: 1-6: 5 \times 10^{-6} \mathrm{~mol} / \mathrm{L} ; \mathrm{C}_{\text {aspartic }}: 1 \times 10^{-8} \mathrm{~mol} / \mathrm{L} ; \mathrm{C}_{\mathrm{DNA}}: 1-6: 0$, $1.03 \times 10^{-5}, 1.85 \times 10^{-5}, 2.88 \times 10^{-5}, 2.47 \times 10^{-5}, 2.06 \times 10^{-5} \mathrm{~mol} / \mathrm{L}$

light scattering unchanged or decreased (Fig. 9). The concentration of DNA at this time is called as the saturated DNA concentration of alizarin binding with DNA. The saturation value binding with DNA of aspartate is 0.24 . Aspartate is an acid, it makes alizarin-DNA system stable and makes alizarin 
intercalate into DNA easily. The reason might be that DNA double helix become loose and reduce the DNA embedded in the space alizarin resistance because of hydrogen binding between carboxyl of polarity and the DNA minor groove and its hydrogen spatial configuration ${ }^{11}$.

Aspartate is a unit of protein which are widely used in the biosynthesis, it can reduce the potential toxicity of alizarin.

Influence of tryptophan on the system of alizarin-DNA: Alizarin $\left(5 \times 10^{-6} \mathrm{~mol} / \mathrm{L}\right)$ and DNA $\left(2.47 \times 10^{-5} \mathrm{~mol} / \mathrm{L}\right)$ are fixed and the intensity of resonance light scattering in the 299 $\mathrm{nm}$ are different with the increasing concentration of tryptophan (Fig. 10). When concentration of tryptophan is $6 \times 10^{-7} \mathrm{~mol} /$ $\mathrm{L}$,influence on the system of alizarin-DNA is greatest. Alizarin $\left(5 \times 10^{-6} \mathrm{~mol} / \mathrm{L}\right)$ and tryptophan $\left(6 \times 10^{-7} \mathrm{~mol} / \mathrm{L}\right)$ are selected, resonance light scattering at $299 \mathrm{~nm}$ gradually enhance with the increasing the concentration of DNA. When the concentration of DNA is greater than $1.65 \times 10^{-5} \mathrm{~mol} / \mathrm{L}$, resonance light scattering unchanged or decreased (Fig. 11). The concentration of DNA at this time is called as the saturated DNA concentration of alizarin binding with DNA. The saturation value binding with DNA of tryptophan is 0.30 . Trytophan contains benzene ring ro a heterocyclic structure, it is similar to structure of anthraquinone. $\pi-\pi$ interaction in this molecular which is easy to intercalate into DNA base pairs. This will increase completive combination of alizarin with $\mathrm{DNA}^{10}$.

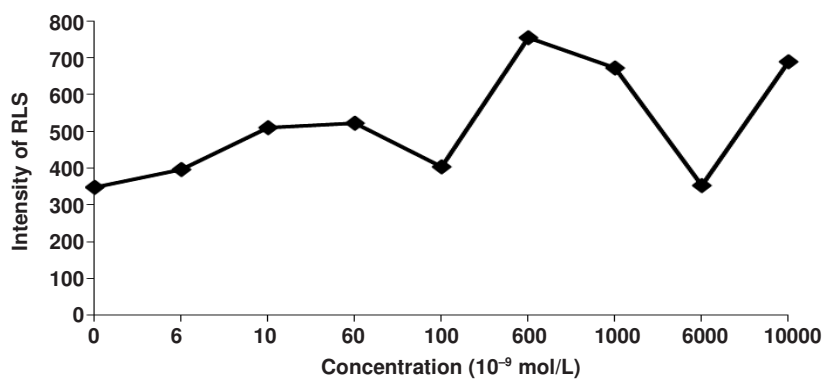

Fig. 10. Resonance scattering intensity of different the concentration of tryptophan on the system of alizarin and DNA

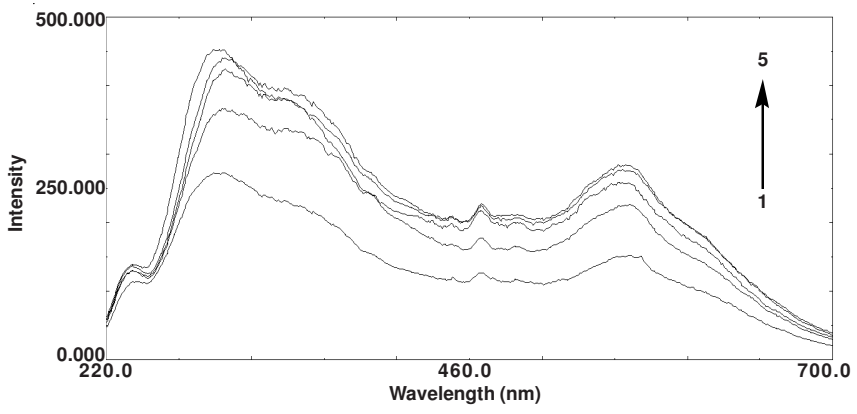

Fig. 11. Resonance scattering intensity of DNA, tryptophan and alizarin $\mathrm{C}_{\text {alizarin }}: 2-7: 5 \times 10^{-6} \mathrm{~mol} / \mathrm{L} ; \mathrm{C}_{\text {tryptophan }}: 6 \times 10^{-7} \mathrm{~mol} / \mathrm{L} ; \mathrm{C}_{\mathrm{DNA}}: 1-5: 0$, $1.03 \times 10^{-5}, 2.47 \times 10^{-5}, 2.06 \times 10^{-5}, 1.65 \times 10^{-5} \mathrm{~mol} / \mathrm{L}$

Tryptophan are essential amino acid for mammals and it is components of some antibiotics. Tryptophan can enhance the toxicity of alizarin, so it should avoid to eating food containing alizarin when taking antibiotics containing tryptophan.

Influence of non-polar amino acids on the system of alizarin-DNA: Alizarin $\left(5 \times 10^{-6} \mathrm{~mol} / \mathrm{L}\right)$ and DNA $\left(2.47 \times 10^{-5}\right.$ $\mathrm{mol} / \mathrm{L}$ ) are fixed and the intensity of resonance light scattering in the $299 \mathrm{~nm}$ are different with the increasing concentration of leucine (Fig. 12). When concentration of leucine is $6 \times 10^{-9}$ $\mathrm{mol} / \mathrm{L}$, influence on the system of alizarin-DNA is greatest. Alizarin $\left(5 \times 10^{-6} \mathrm{~mol} / \mathrm{L}\right)$ and leucine $\left(6 \times 10^{-9} \mathrm{~mol} / \mathrm{L}\right)$ are selected, resonance light scattering at $299 \mathrm{~nm}$ gradually enhance with the increasing the concentration of DNA. When the concentration of DNA is greater than $2.47 \times 10^{-5} \mathrm{~mol} / \mathrm{L}$, resonance light scattering unchanged or decreased (Fig. 13). The concentration of DNA at this time is called as the saturated DNA concentration of alizarin binding with DNA. The saturation value binding with DNA of leucine is 0.20 .

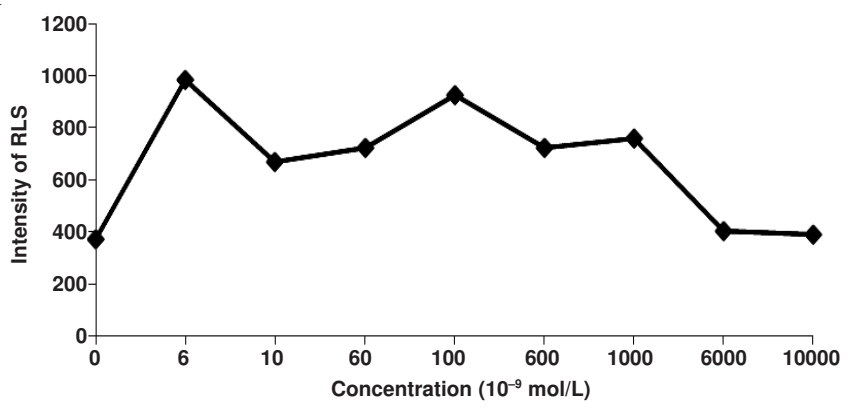

Fig. 12. Resonance scattering intensity of different the concentration of leucine on the system of alizarin and DNA

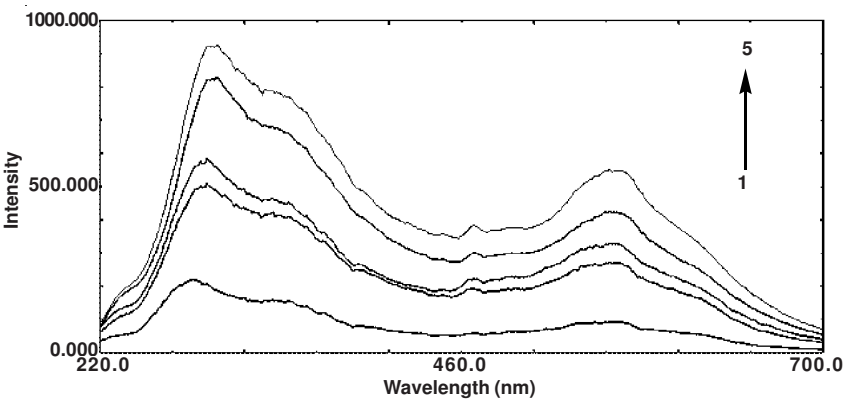

Fig. 13. Resonance scattering intensity of DNA, leucine and alizarin $\mathrm{C}_{\text {alizarin }}$ $2-7: 5 \times 10^{-6} \mathrm{~mol} / \mathrm{L} ; \mathrm{C}_{\text {leucine }}: 6 \times 10^{-9} \mathrm{~mol} / \mathrm{L} ; \mathrm{C}_{\mathrm{DNA}}: 1-5: 0,1.65 \times 10^{-5}$, $2.06 \times 10^{-5}, 3.30 \times 10^{-5}, 2.47 \times 10^{-5} \mathrm{~mol} / \mathrm{L}$

Alizarin $\left(5 \times 10^{-6} \mathrm{~mol} / \mathrm{L}\right)$ and DNA $\left(2.47 \times 10^{-5} \mathrm{~mol} / \mathrm{L}\right)$ are fixed and the intensity of resonance light scattering in the $299 \mathrm{~nm}$ are different with the increasing concentration of valine (Fig. 14). When concentration of valine is $1 \times 10^{-8} \mathrm{~mol} /$ $\mathrm{L}$, influence on the system of alizarin-DNA is greatest. Alizarin $\left(5 \times 10^{-6} \mathrm{~mol} / \mathrm{L}\right)$ and valine $\left(1 \times 10^{-8} \mathrm{~mol} / \mathrm{L}\right)$ are selected, resonance light scattering at $299 \mathrm{~nm}$ gradually enhance with the increasing the concentration of DNA. When the concentration of DNA is greater than $2.47 \times 10^{-5} \mathrm{~mol} / \mathrm{L}$, resonance light scattering unchanged or decreased (Fig. 15). The concentration of DNA at this time is called as the saturated DNA concentration of alizarin binding with DNA. The saturation value binding with DNA of valine is 0.20 .

Leucine and valine are neutral aliphatic amino acids. They have no effects on the system of alizarin-DNA and the saturation value binding with DNA. Although the saturation value binding with DNA are the same, resonance light scattering spectrum are different.

Leucine and valine are glucogenic amino acid and essential amino acid for bodies. They have no influence on the toxicity of alizarin, so there is no need to consider the leucine and valine when eating food containing alizarin. 


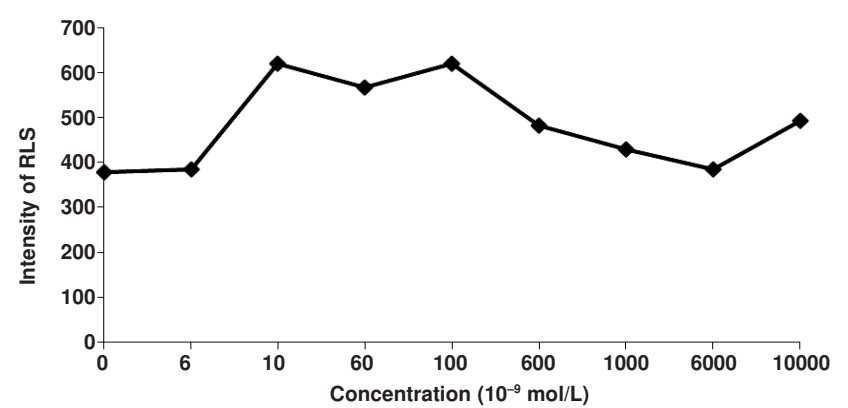

Fig. 14. Resonance scattering intensity of different the concentration of valine on the system of alizarin and DNA

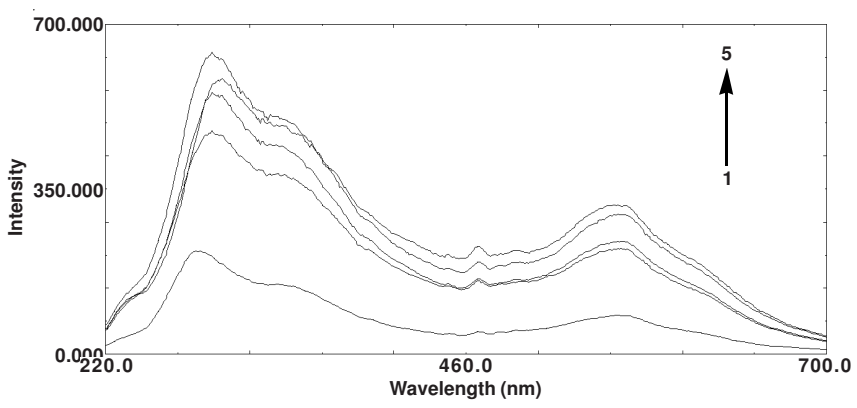

Fig. 15. Resonance scattering intensity of DNA, valine and alizarin $\mathrm{C}_{\text {alizarin }}$ : $2-7: 5 \times 10^{-6} \mathrm{~mol} / \mathrm{L} ; \mathrm{C}_{\text {valine }}: 1 \times 10^{-8} \mathrm{~mol} / \mathrm{L} ; \mathrm{C}_{\mathrm{DNA}}: 1-5: 0,1.65 \times 10^{-5}$, $2.06 \times 10^{-5}, 3.30 \times 10^{-5}, 2.47 \times 10^{-5} \mathrm{~mol} / \mathrm{L}$

Influence of $\mathrm{pH}$ on the system of alizarin-DNA: Alizarin $\left(5 \times 10^{-6} \mathrm{~mol} / \mathrm{L}\right)$ and DNA $\left(2.47 \times 10^{-5} \mathrm{~mol} / \mathrm{L}\right)$ are fixed and the intensity of resonance light scattering in the $299 \mathrm{~nm}$ are different with the increasing $\mathrm{pH}$ value (Fig. 16). At $\mathrm{pH}=7.46$, resonance light scattering signal of alizarin-DNA system reached maximum. DNA in the nearly neutral environment are relatively stable. It will hinder alizarin to intercalate into DNA in acidic or alkaline environment. The saturation values binding with DNA at $\mathrm{pH} 6.44, \mathrm{pH} 7.46$ and $\mathrm{pH} 8.21$ are 0.17 (Fig. 1), 0.20 (Fig. 17) and 0.19 (Fig. 18) respectively. DNA have positive charge at $\mathrm{pH} 6.44$. The phosphate anion of DNA molecules can not combine with $\mathrm{H}^{+}$while acid medium increase. Then arizarin can not close to DNA by electrostatic and then the amount of alizarin interaction with DNA reduce. DNA have negative charge at pH 8.21. DNA double helix melt into single-stranded DNA, this makes binding site for alizarin intercalating into DNA reduce ${ }^{14}$.

Human body fluid is weak alkaline and the food eated daily are acid. Both weak alkaline human body fluid and acid food are helpful to reduce the toxicity of alizarin.

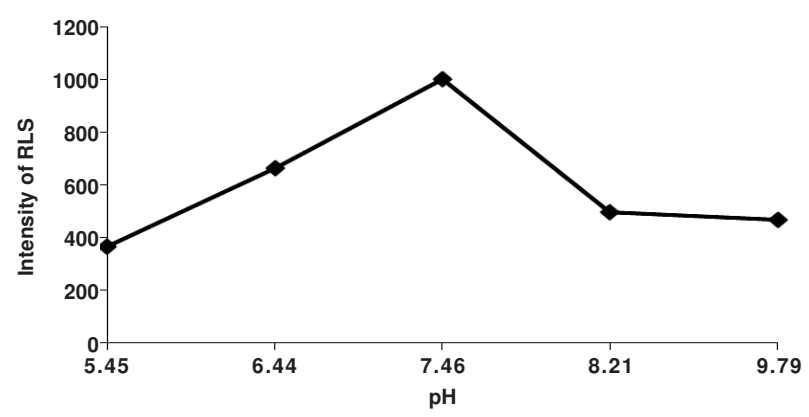

Fig. 16. Resonance scattering intensity of different $\mathrm{pH}$ on the system of alizarin and DNA

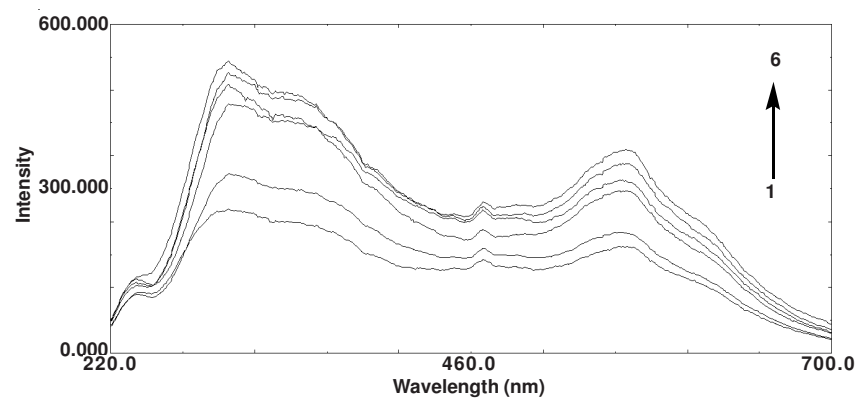

Fig. 17. Resonance light scatting spectra of DNA, pH 6.44 and alizarin $\mathrm{C}_{\text {alizarin }}: 2-7: 5 \times 10^{-6} \mathrm{~mol} / \mathrm{L} ; \mathrm{C}_{\mathrm{DNA}}: 1-6: 0,2.06 \times 10^{-5}, 2.47 \times 10^{-5}$, $2.68 \times 10^{-5}, 1.03 \times 10^{-5}, 2.88 \times 10^{-5} \mathrm{~mol} / \mathrm{L}$

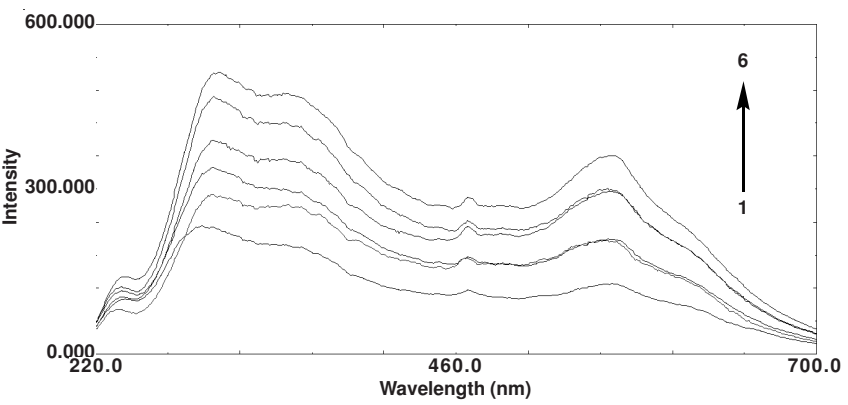

Fig. 18. Resonance light scatting spectra of $\mathrm{DNA}, \mathrm{pH} 8.21$ and alizarin $\mathrm{C}_{\text {alizarin }}$ $2-7: 5 \times 10^{-6} \mathrm{~mol} / \mathrm{L} ; \mathrm{C}_{\mathrm{DNA}} 1-6: 0,1.03 \times 10^{-5}, 2.06 \times 10^{-5}, 2.47 \times 10^{-}$ $5,2.88 \times 10^{-5}, 2.68 \times 10^{-5} \mathrm{~mol} / \mathrm{L}$

Influence of sodium chloride on the system of alizarinDNA: Alizarin $\left(5 \times 10^{-6} \mathrm{~mol} / \mathrm{L}\right)$ and DNA $\left(2.47 \times 10^{-5} \mathrm{~mol} / \mathrm{L}\right)$ are fixed and the intensity of resonance light scattering in the $299 \mathrm{~nm}$ are different with the increasing concentration of sodium chloride (Fig. 19). When concentration of sodium chloride is $6 \times 10^{-7} \mathrm{~mol} / \mathrm{L}$, influence on the system of alizarinDNA is maximum. Alizarin $\left(5 \times 10^{-6} \mathrm{~mol} / \mathrm{L}\right)$ and sodium chloride $\left(6 \times 10^{-7} \mathrm{~mol} / \mathrm{L}\right)$ are selected, resonance light scattering at $299 \mathrm{~nm}$ gradually enhance with the increasing the concentration of DNA. When the concentration of DNA is greater than $1.24 \times 10^{-5} \mathrm{~mol} / \mathrm{L}$, resonance light scattering unchanged or decreased (Fig. 20). The concentration of DNA at this time is called as the saturated DNA concentration of alizarin binding with DNA. The saturation value binding with DNA of sodium chloride is 0.40 . DNA molecular are surrounded by a lot of sodium chloride, this makes alizarin intercalate into DNA easily and alizarin-DNA system become stable.

Sodium chloride greatly increase the potential toxicity of alizarin. So it is better to try to eat some food with low salt to avoid increase of potential toxicity of alizarin resulted from the sodium chloride in the daily life.

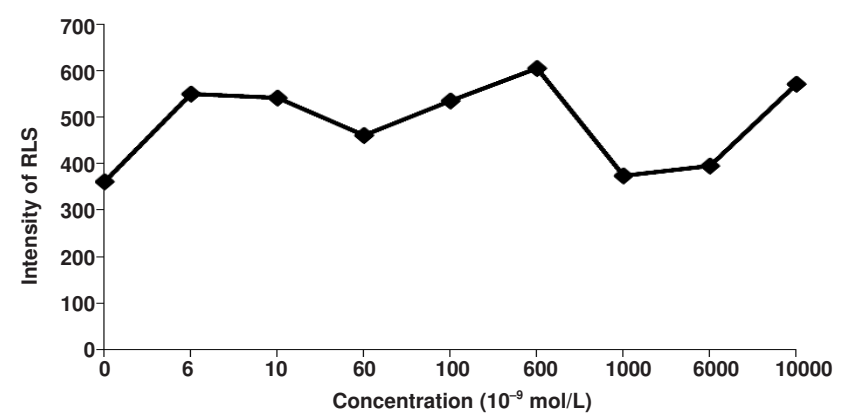

Fig. 19. Resonance scattering intensity of different the concentration of sodium chloride on the system of alizarin and DNA 


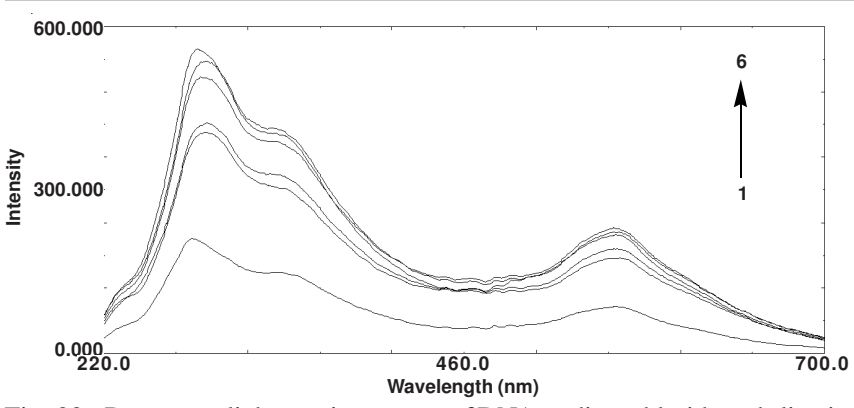

Fig. 20. Resonance light scatting spectra of DNA, sodium chloride and alizarin $\mathrm{C}_{\text {alizarin }} 1-6: 5 \times 10^{-6} \mathrm{~mol} / \mathrm{L} ; \mathrm{C}_{\text {sodium chloride }} 6 \times 10^{-7} \mathrm{~mol} / \mathrm{L} ; \mathrm{C}_{\mathrm{DNA}}$ : 1-6:2.88 $\times$ $10^{-5}, 2.47 \times 10^{-5}, 2.06 \times 10^{-5}, 1.65 \times 10^{-5}, 1.24 \times 10^{-5} \mathrm{~mol} / \mathrm{L}$

Influence of glucose on the system of alizarin-DNA: Alizarin $\left(5 \times 10^{-6} \mathrm{~mol} / \mathrm{L}\right)$ and DNA $\left(2.47 \times 10^{-5} \mathrm{~mol} / \mathrm{L}\right)$ are fixed and resonance light scattering in the $299 \mathrm{~nm}$ are different (Fig. 21). When concentration of glucose is $6 \times 10^{-7} \mathrm{~mol} / \mathrm{L}$, influence on the system of alizarin-DNA is greatest. Alizarin $\left(5 \times 10^{-6} \mathrm{~mol} / \mathrm{L}\right)$ and glucose $\left(6 \times 10^{-7} \mathrm{~mol} / \mathrm{L}\right)$ are selected, resonance light scattering at $299 \mathrm{~nm}$ gradually enhance with the increasing the concentration of DNA. When the concentration of DNA is greater than $2.68 \times 10^{-5} \mathrm{~mol} / \mathrm{L}$, resonance light scattering unchanged or decreased (Fig. 22). The concentration of DNA at this time is called as the saturated DNA concentration of alizarin binding with DNA. The saturation value binding with DNA of sodium chloride is 0.17 . Glucose makes DNA double helix become tight by interaction with DNA through hydrogen. It is difficult for alizarin close to DNA, so the saturation value binding with DNA decrease.

Glucose was widely used in candy manufacture and the potential toxicity of alizarin can be reduced by it, so it is no use to worry about the increase of potential toxicity of alizarin when eating foods containing the alizarin.

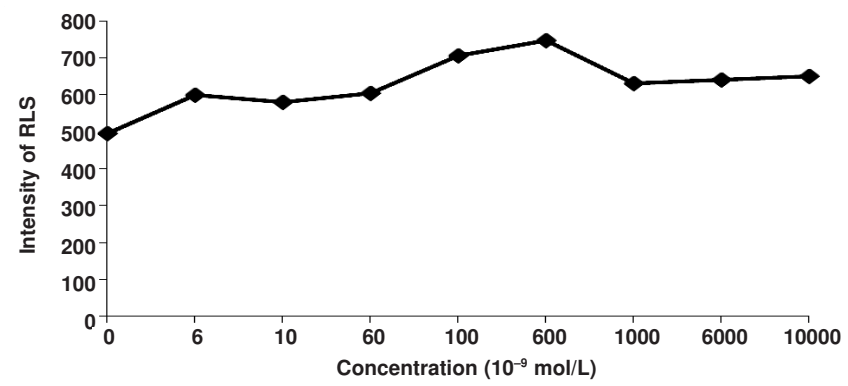

Fig. 21. Resonance scattering intensity of different the concentration of glucose on the system of alizarin and DNA

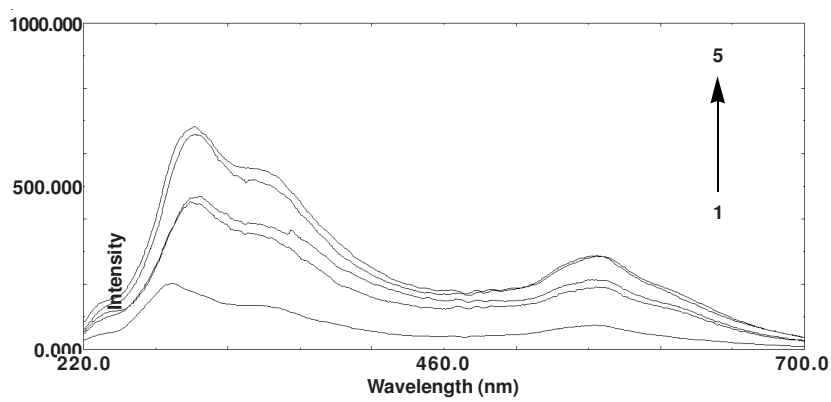

Fig. 22. Resonance light scatting spectra of DNA, glucose and alizarin $\mathrm{C}_{\text {alizarin }}: 1-6: 5 \times 10^{-6} \mathrm{~mol} / \mathrm{L} ; \mathrm{C}_{\text {glucose }}: 6 \times 10^{-7} \mathrm{~mol} / \mathrm{L} ; \mathrm{C}_{\mathrm{DNA}}: 1-5: 0,3.09$ $\times 10^{-5}, 2.88 \times 10^{-5}, 2.47 \times 10^{-5}, 2.68 \times 10^{-5} \mathrm{~mol} / \mathrm{L}$

\section{Conclusion}

We study the interaction of alizarin and DNA to reveal the toxicity of alizarin by resonance light scattering spectrum. The saturation value binding DNA is calculated from the resonance light scattering and compared with mitoxantrone, chrysophanol and rhein. It can evaluate the ability of intercalating into DNA and the potential toxicity of anthraquinone molecule. The saturation value changes when environmental factors about bodies such as amino acids, sodium chloride, glucose and $\mathrm{pH}$ change (Table-3). The situation value binding with DNA can evaluate the potential toxicity of anthraquione derivatives and its toxic effects in terms of external conditions and factors. The aim of this paper is to provide a theoretical basis in using alizarin.

\begin{tabular}{|c|c|c|}
\hline \multicolumn{3}{|c|}{$\begin{array}{c}\text { TABLE-3 } \\
\text { CHANGE RATE OF THE SATURATION VALUE } \\
\text { BINDING WITH DNA }\end{array}$} \\
\hline Environmental conditions & AA & $\mathrm{BB}(\%)$ \\
\hline Alizarin-DNA-pH 7.46 & 0.20 & - \\
\hline Alizarin-DNA-leucine-pH 7.46 & 0.20 & 0 \\
\hline Alizarin-DNA-valine-pH 7.46 & 0.20 & 0 \\
\hline Alizarin-DNA-histidine-pH 7.46 & 0.19 & -5 \\
\hline Alizarin-DNA-aspartate-pH 7.46 & 0.24 & +20 \\
\hline Alizarin-DNA-tryptophan-pH 7.46 & 0.30 & +50 \\
\hline Alizarin-DNA-sodium chloride-pH 7.46 & 0.40 & +100 \\
\hline Alizarin-DNA-glucose-pH 7.46 & 0.17 & -15 \\
\hline Alizarin-DNA-pH 6.44 & 0.17 & -15 \\
\hline Alizarin-DNA-pH 8.21 & 0.19 & -5 \\
\hline \multicolumn{3}{|c|}{$\begin{array}{l}\mathrm{AA}=\text { Saturation value binding with DNA; BB }=\text { Change rate of the } \\
\text { saturation value binding with DNA (with alizarin-DNA-pH } 7.46 \text { as a } \\
\text { standard) }\end{array}$} \\
\hline \multicolumn{3}{|c|}{ ACKNOWLEDGEMENTS } \\
\hline
\end{tabular}

This study was supported by China Natural Science Foundation of Guangxi (2010GXNSFA013134).

\section{REFERENCES}

1. D. De Santis and M. Moresi, Ind. Crop. Prod., 26, 151 (2007).

2. J. Liu, D. Guo, Y. Zhou, Z. Wu, W. Li, F. Zhao and X. Zheng, J. Archaeol. Sci., 38, 1763 (2006).

3. G.G. Balakina, V.G. Vasiliev, E.V. Karpova, V.I. Mamatyuk, Dyes Pigments, 71, 54 (2006).

4. L. Tikkanen, T. Matsushima and S. Natori, Mutat. Res., 116, 297 (1983).

5. K. Inoue, M. Yoshida, M. Takahashi, H. Fujimoto, M. Shibutani, M. Hirose and A. Nishikawa A., Cancer Sci., 100, 2261 (2009).

6. K. Inoue, M. Yoshida, M. Takahashi, H. Fujimoto, K. Ohnishi, K. Nakashima, M. Shibutani, M. Hirose and A. Nishikawa, Food Chem. Toxicol., 47, 752 (2009).

7. L.E. Sendelbach, Toxicology, 57, 227 (1989).

8. B.E. Butterworth, O.B. Mathre, K.E. Ballinger and O. Adalsteinsson, Int. J. Toxicol., 23, 335 (2004).

9. K. Inoue, M. Shibutani, N. Masutomi, K. Toyoda, H. Takagi, M. Takahashi, H. Fujimoto, M. Hirose and A. Nishikawa, Food Chem. Toxicol., 46, 3303 (2008).

10. X-M. Yang, J.-S. Li, Q.Q. Li, G.X. Huang and L.J. Yan, Asian J. Chem., 23, 3631 (2011).

11. Y. Lu, M.Sc. Thesis, Study of Potential Cytotoxicity in Rhubarb Anthraquinone Derivatives and the Mechanism of Rhubarb De-toxicity by Compatibility Based on Spectroscopy, Guangxi University of Technology (2010).

12. X-M. Yang, J.-S. Li, Q.Q. Li, G.X. Huang and L.J. Yan, Asian J. Chem., 24, 551 (2012).

13. X.-M. Yang, M.Sc. Thesis, Study of Toxic Mechanism of Anthraquinone Derivatives Binding DNA by the Resonance Light Scattering, Guangxi University of Technology (2011).

14. C.V. Kumar and E.H. Asuncion, J. Am. Chem. Soc., 115, 8547 (1993). 